\title{
Dental plaque - A microbial perspective and recent concepts as a host and guest relation
}

\author{
Akhilanand Chaurasia ${ }^{1, *}$, Akansha Vatsa ${ }^{2}$ \\ ${ }^{1}$ Assistant Professor, ${ }^{2}$ Resident, Dept. of Oral Medicine \& Radiology, Faculty of Dental Sciences, King George’s Medical \\ University, Lucknow, Uttar Pradesh, India
}

*Corresponding Author:

Email: chaurasiaakhilanand49@gmail.com

\begin{abstract}
Dental plaque is defined clinically as a structured, resilient yellow grayish substance that adheres tenaciously to the intra-oral hard surfaces i.e teeth including removable and fixed restorations. It is primarily composed of micro-organisms. One gram of plaque contains approximately $10^{\mathbf{1 1}}$ bacteria. Any individual may harbor 150 or more different species. Non bacterial microorganisms that are found in plaque include archaea, yeasts, protozoa and viruses. Nowadays application of novel imaging and molecular techniques has created great understanding about dental plaque. This article is an insight of host and guest relation of dental plaque in terms of micro-organisms as guest and humans as host.
\end{abstract}

Keywords: Dental plaque, Biofilm, Oral Microflora.

\section{Introduction}

The existence of bacteria in nature is mostly in the form of biofilm. Biofilm is comprised of consortium of interacting species. Studies on microbial ecology ${ }^{1}$ and the knowledge of the interaction between the resident human microflora and the host has provided sound base for our understanding regarding microbial behaviour. The gene expression in microflora is highly affected by changes in host environment which also has great impact on the metabolic activity, competitivity and composition of that microbial community. In turn these resident microorganisms also have impact on host physiology as well as pathology. Nowadays application of novel imaging and molecular techniques has created great understanding about dental plaque.

Out of 1014 cells in human body only 10\% are mammalian. ${ }^{2,3}$ The environmentally exposed surfaces of the body consists of majority of microorganisms of the resident flora whose combined metabolic activity is reported as equivalent to that of the human liver. Despite of potential movements of the microorganisms between different sites of body sites, the distinct biological and physical properties of skin, mouth, digestive and reproductive tracts etc results in distinctive micro flora of each site. ${ }^{3}$

These findings conclude about habitat's selective and dictating properties which decides the colonization, membership and growth of respective microbes. Similarly the oral cavity also has a characteristic microbial community benefiting the host. Warmth and moisture of mouth support the growth of certain specific group of microorganisms (viruses, mycoplasma, bacteria, Archaea, fungi and protozoa), ${ }^{4}$ out of which bacteria are the most numerous group. ${ }^{5,6}$ Less than $50 \%$ of the resident oral micro flora can currently be cultivated in pure culture in the laboratory. ${ }^{7,8}$ Newer culture-independent molecular approaches have greatly improved our concepts about the richness and diversity of the resident oral micro flora. Amplification, cloning and sequencing techniques of the 16S rRNA gene have identified approximately 700 species in the mouth while the number of species per individual mouth ranged from 34 to $72 .{ }^{9}$ However, the use of a more discriminatory pyro-sequencing rendered above as an under-estimation as this advanced approach detected several thousands of phylotypes in samples of saliva and supra-gingival plaque from healthy adults. ${ }^{10}$ In this, a next-generation highthroughput sequencing technique is used which resulted in an increased number of clones that can be sequenced causing increased the chances of detection of the less abundant taxa.

Resident micro flora obtains their primary nutrients mainly from endogenous sources such as amino acids, proteins and glycoproteins in saliva and gingival crevicular fluid whereas the host diet has a minor role to plays. Combined co-operated metabolic capabilities of the microbial consortia helps in catabolism of the more complex host molecules. ${ }^{11-16}$ Neutral $\mathrm{pH}$ of saliva also promotes the growth of many microorganisms. Early aerobic bacterial colonizers (e.g. Neisseria spp.) or facultatively anaerobic (e.g. Streptococcus and Actinomyces spp.) and other gases (CO2, H2) and reduced lower the redox potential of dental plaque which create environment for the growth of obligate anaerobes. ${ }^{4}$ In this way a precise spatial organization of interacting bacteria is created in the plaque (e.gStreptococci and Fusobacterium nucleatum) whose composition also varies within distinct sites in oral cavity.

\section{Formation of dental plaque}

This involve certain steps. At first there is formation of enamel pellicle by adsorbtion of molecules 
from saliva and gingival crevicular fluid to the tooth surface. Then reversible attachment of microoraganisms to it occurs by weak, long-range, physico-chemical interactions between the charge on the microbial cell surface and that produced by the conditioning film i.e pellicle. ${ }^{17,18}$ Transport of microorganisms is usually passive to the surface by the flow of saliva or gingival crevicular fluid whereas a few species (e.g. Wolinella, Selenomonas and Campylobacter spp.) are found subgingivally and have flagella and are motile. Then microorganisms get attached irreversibly by strong and short distance interactions between adhesins on microbes and receptors present in the acquired pellicle which opens the gateway for novel interventions aimed at blocking colonization. ${ }^{19}$ Co-attachment i.e coadhesion takes place where secondary and late colonizers adhere via cell-surface adhesins to receptors on already attached bacteria. ${ }^{20,21}$ The multiplication of the adherent cells by increase in biomass and synthesis of matrix of the biofilm occurs by synergistic interaction between neighbouring species. Bacteria adapts to fluctuating environmental changes and contradictory growth requirements by altering their patterns of gene expression., ${ }^{4,22-24}$

In deteriorated circumstances some species (e.g. Prevotella loescheii and Aggregatibacter actinomycetem comitans) upregulate enzymes that cleave their adhesions and enable them to detach and colonize elsewhere. ${ }^{25,26}$ The changes in community composition and activity may predispose a site to disease. Different forms of microbial arrangements (e.g. corn cob, test tube, brush or rosette) exist within subgingival dental plaque.

\section{Properties of dental plaque as biofilm}

Dental plaque as biofilm holds many important properties. ${ }^{4}$ They have an open architecture with presence of channels and voids. They provide microbial protection, host protection, colonization and gene transfer. Neutralization of inhibitors also occurs within it by beta-lactamase production by neighbouring cells to protect sensitive organisms. Novel gene expression occurs via coordinated gene responses by producing bacterial cell-to-cell signalling molecules (e.g. CSP, AI2). They also communicate with host for e.g down regulation of pro-inflammatory responses by resident oral bacteria. Co-adhesion is also a prime feature. Biofilm has a broader habitat range (obligate anaerobes in an overtly aerobic environment). Efficient metabolism like complete catabolism of complex host macromolecules also takes place. It also has enhanced virulence.

\section{Interactions within biofilm}

Metabolic product of one organism serves as the primary nutrient for another microorganism. Bacterial collaboration also aids in catabolism of complex host molecules (proteins, glycoproteins). ${ }^{11,16}$ Similarly obligately anaerobic bacteria such as P. gingivalis can survive in aerobic environments on their collaboration with oxygen-consuming species such as Neisseria. ${ }^{27,28}$ So some bacteria appear in plaque biofilms as discrete clusters of cells. Bacterial gene expression occurs in a coordinated manner in dental plaque via quorum sensing. ${ }^{29-31}$ Transformation frequency of biofilmgrown S. mutans is increased $10-600$ folds via quorum sensing mediated by CSP i.e competence stimulating peptide. ${ }^{32}$ It also increases cells property of tolerance to acids. ${ }^{33}$ Similarly Lux-S dependent signaling enhances efficiency of A. actinomycetemcomitans and P.gingivalis ${ }^{34}$ (11). These molecules play evident role in intra and inter-species communication and coordination as AI-2 produced by A. actinomycetemcomitans complemented a lux-S mutation in $\mathrm{P}$. gingivalis and AI-2 secretion by $\mathrm{P}$. gingivalis could stimulate biofilm formation by $\mathrm{F}$. nucleatum. ${ }^{31,35}$ Another mechanism of cellular interaction within biofilms is horizontal gene transfer. For e.g transfer of conjugative transposons encoding tetracycline resistance amongst streptococci. ${ }^{36}$ The presence of pathogenicity islands in periodontal pathogens such as $\mathrm{P}$. gingivalis may explain the evolution of more virulent strains due to horizontal gene transfer. ${ }^{37}$

\section{Microbial gene expression in biofilm}

Microorganisms also alter their gene expression in order to survive $e^{38-40}$ in the changing habitat environment as in case of disease. Increased sugar consumption frequency results in rapid formation of acid from fermentable carbohydrates causing caries. This cause the decrease in local $\mathrm{pH}$ and increase in acidogenic and acidophilic bacterial growth. ${ }^{38,41,42}$ Similarly in periodontal disease, apart from providing components of the host defences, increased gingival crevicular flow also introduces a range of host proteins and glycoproteins which are used as substrates for growth by many of the obligate anaerobic and proteolytic species present in subgingival biofilms. ${ }^{16,43}$ The inflammation also alters gene expression for example, P. gingivalis become more proteolytic with higher gingival pain activity in response to an increase in haemin availability ${ }^{44,45}$ due to differential expression of $70 \mathrm{~S}$ proteins ${ }^{41}$ whereas a high temperature resulted in down-regulation of protease activity in P. gingivalis. ${ }^{46}$ So the changes in subgingival environment results in a shift in both the competitiveness and aggressiveness of previously minor components of the microflora. This may result in increased risk of disease due to disruption of the natural balance of organisms and modification of the composition of the microflora. ${ }^{41}$ Genes associated with glucan and fructan synthesis in S.mutans i.e matrix formation were found to be differentially regulated in biofilms. ${ }^{47}$ In early biofilm formation $(<48 \mathrm{~h})$ surface growth didn't influenced gene expression much while in older biofilms(7-day), glucan expression was 
markedly upregulated and fructan activity was repressed. ${ }^{47,48}$ When P. gingivalis was grown as a biofilm, approximately $18 \%$ of the genome was differentially expressed. ${ }^{48}$

\section{Impact of dental plaque as a biofilm on host}

There is a major role of resident microflora in aiding host defence by "colonization resistance". It also enhances physiological and nutritional development of host as the gut of germ free animals was poorly developed. When these animals are colonized with members of resident microflora, the deficiencies were reversed. ${ }^{49-54}$ Resident microflora also determine normal expression of immune mediators. ${ }^{55}$ The disruption of host-microbe balance leads to disease. 52,53,56,57 Gene expression in both bacterial and host cells is affected by signaling amongst them via receptors for e.g Toll-like receptors and NOD-like recetors..$^{51,52,56,58}$ By inhibiting the nuclear factor kappa B pathway, Streptococcus salivarius K12 down-regulates epithelial cell inflammatory responses as well as stimulates type I and II interferon responses and also exerts significant effects on the cytoskeleton and adhesive properties of the host cell. ${ }^{59}$ Formation of integrin-associated focal adhesions which cause remodelling of the actin and tubulin cytoskeleton in primary gingival epithelial cells is induced by Fimbriated P. gingivalis cells. ${ }^{60}$ In healthy states, putative periodontal pathogens are noncompetitive with beneficial micro flora and remain at low levels. Host inflammatory responses are mounted if plaque accumulates beyond health compatible levels. This leads to increased gingival crevicular flow which further provides nutrient source to proteolytic gramnagative anaerobes predisposing disease sites. Resultant proteolysis increase local $\mathrm{pH}$ causing upregulation of virulence factors of these putative pathogens (e.g. gingival pain activity by $\mathrm{P}$. gingivalis) promoting their growth at the expense of health related microbes. ${ }^{16,43,61}$ This dynamic relationship, resulting in disease process is explained by 'ecological plaque hypothesis'. ${ }^{41,62}$ Replacement therapy with 'beneficial' bacteria and manipulation by use of pre- or probiotics is also under evaluation. ${ }^{63,64}$

\section{Dental plaque: resistance against antimicrobial agents}

Being in a community, the biofilm provides a broader habitat range to microorganisms. ${ }^{18,28,65}$ It promotes more efficient metabolism of complex host derived products ${ }^{\mathbf{1 5 , 6 6}}$. It reinforces microbes to tackle inhibitory agents and host defenses more efficiently ${ }^{67-69}$ as well as enhance their virulence. ${ }^{70-74}$

300 times greater concentrations of chlorhexidine and 75 times greater concentrations of amine fluoride than the minimum bactericidal concentration against planktonic cells are required to kill Streptococcus sobrinus growing as an established biofilm. ${ }^{75}$ The more the age of biofilm, the more will be the tolerance. ${ }^{76,77}$
Biofilms with more diverse environment have proved to be more tolerant to amoxycillin, doxycycline, minocycline and metronidazole than planktonic cells. ${ }^{77-}$ ${ }^{80}$ Either the quenching of the agent at the biofilm surface or a lack of penetration causes chlorhexidine to only affect the outer layers of cells in 24 and 48 hrs plaque biofilms as shown in conofocal microscopy of in-situ established natural biofilms. ${ }^{81}$ Similarlly fluoride also shows uneven distribution within biofilm. ${ }^{82}$ Bacteria that grow in the depths of biofilms generally divide slowly and thus are always less sensitive to antimicrobial agents.

\section{Conclusion}

There occurs a harmonious relationship between host and resident flora. Change in local environmental factor causes disruption of host-microbe balance predisposing and potentiating disease process. Rather than just focusing upon mere presence or absence of putative pathogenic species, it is needed to expand the dimensions of knowledge regarding their proportions and combinations. Additionally role of reduction in beneficial bacteria in disease process must be considered. The aim of oral health care programme should concern regarding controlling the levels and activity of the oral microflora, rather than focusing on their elimination.

\section{References}

1. Alexander M. Microbial ecology. New York: John Wiley, 1971.

2. Sanders WE, Sanders CC. Modification of normal flora by antibiotics: effects on individuals and the environment. In: Koot RK, Sande MA, editors. New dimensions in antimicrobial chemotherapy. New York: Churchill Livingstone, 1984:217-41.

3. Wilson M. Microbial inhabitants of humans. Their ecology and role in health and disease. Cambridge, UK: Cambridge University Press, 2005.

4. Marsh PD, Martin MV. Oral microbiology, 5th edition. Edinburgh, UK:Churchill Livingstone, 2009.

5. Choi BK, Paster BJ, Dewhirst FE, Gobel UB. Diversity of cultivable and uncultivable oral spirochetes from a patient with severe destructive periodontitis. Infect Immun 1994:62:1889-95.

6. Paster BJ, Bosches SK, Galvin JL, Ericson RE, Lau CN, Levanos VA, Sahasrabudhe A, Dewhirst FE. Bacterial diversity in human subgingival plaque. J Bacteriol 2001:183:3770-83.

7. Wade W. Unculturable bacteria - the uncharacterized organisms that cause oral infections. J R Soc Med 2002:95:81-3.

8. Wade W. Unculturable bacteria in oral biofilms. In: Newman HN, Wilson M, editors. Dental plaque revisited. Cardiff, UK: BioLine, 1999:313-22.

9. Aas JA, Paster BJ, Stokes LN, Olsen I, Dewhirst FE. Defining the normal bacterial flora of the oral cavity. $J$ Clin Microbiol 2005:43:5721-32.

10. Keijser BJ, Zaura E, Huse SM, van der Vossen JM, Schuren FH, Montijn RC, ten Cate JM, Crielaard W. Pyrosequencing analysis of the oral microflora of healthy adults. J Dent Res 2008:87:1016-20. 
11. Bradshaw DJ, Homer KA, Marsh PD, Beighton D. Metabolic cooperation in oral microbial communities during growth on mucin. Microbiol 1994: 140:3407-12.

12. Homer KA, Beighton D. Synergistic degradation of bovine serum albumin by mutans streptococci and other dental plaque bacteria. FEMS Microbiol Lett 1992:90:259-62.

13. Homer KA, Beighton D. Synergistic degradation of transferring by mutans streptococci in association with other dental plaque bacteria. Microb Ecol Health Dis 1992:5:111-6.

14. Palmer RJ Jr, Diaz PI, Kolenbrander PE. Rapid succession within the Veillonella population of a developing human oral biofilm in situ. J Bacteriol 2006:188:4117-24.

15. Periasamy S, Kolenbrander PE. Aggregatibacter actinomycetemcomitans builds mutualistic biofilm communities with Fusobacterium nucleatum and Veillonella species in saliva. Infect Immun 2009:77:3542-51.

16. Ter Steeg PF, van der Hoeven JS. Development of periodontal microflora on human serum. Microb Ecol Health Dis 1989:2:1-10.

17. Bos R, van der Mei HC, Busscher HJ. Physico-chemistry of initial microbial adhesive interactions - its mechanisms and methods for study. FEMS Microbiol Rev 1999:23:179-230.

18. Chalmers NI, Palmer RJ Jr, Cisar JO, Kolenbrander PE. Characterization of a Streptococcus sp.-Veillonella sp. community micromanipulated from dental plaque. $J$ Bacteriol 2008:190:8145-54.

19. Whittaker CJ, Klier CM, Kolenbrander PE. Mechanisms of adhesion by oral bacteria. Anпи Rev Microbiol 1996:50:513-52.

20. Kolenbrander PE, Andersen RN, Kazmerak KM, Palmer RJ. Coaggregation and coadhesion in oral biofilms. In: Allison DG, Gilbert P, Lappin-Scott HM, Wilson M, editors. Community structure and co-operation in biofilms. Cambridge, UK: Cambridge University Press, 2000:65-85.

21. Kolenbrander PE, Palmer RJ Jr, Rickard AH, Jakubovics NS, Chalmers NI et al. Bacterial interactions and successions during plaque development. Periodontol 2000 2006:42:47-79.

22. Allison DG. The biofilm matrix. Biofouling 2003:19:139-150.

23. Branda SS, Vik S, Friedman L, Kolter R. Biofilms: the matrix revisited. Trends Microbiol 2005:13:20-6.

24. Kuramitsu HK, He X, Lux R, Anderson MH, Shi W. Interspecies interactions within oral microbial communities. Microbiol Mol Biol Rev 2007:71:653-70.

25. Cavedon K, London J. Adhesin degradation: a possible function for a Prevotella loescheii protease? Oral Microbiol Immunol 1993:8:283-7.

26. Kaplan JB, Meyenhofer MF, Fine DH. Biofilm growth and detachment of Actinobacillus actinomycetemcomitans. J Bacteriol 2003:185:1399-404.

27. Bradshaw DJ, Marsh PD, Watson GK, Allison C. Oral anaerobes cannot survive oxygen stress without interacting with aerobic/facultative species as a microbial community. Lett Appl Microbiol 1997: 25: 385-387.

28. Bradshaw DJ, Marsh PD, Watson GK, Allison C. Role of Fusobacterium nucleatum and coaggregation in anaerobe survival in planktonic and biofilm oral microbial communities during aeration. Infect Immun 1998:66:4729- 32 .
29. Cvitkovitch DG, Li YH, Ellen RP. Quorum sensing and biofilm formation in streptococcal infections. J Clin Invest 2003:112:1626-32.

30. Kolenbrander PE, Andersen RN, Blehert DS, Egland PG, Foster JS, Palmer RJ. Communication among oral bacteria. Microbiol Mol Biol Rev 2002:66:486-550.

31. Suntharalingam P, Cvitkovitch DG. Quorum sensing in streptococcal biofilm formation. Trends Microbiol 2005: 13: 3-6.

32. Li Y-H, Tang N, Aspiras MB, Lau PCY, Lee JH, Ellen RP, Cvitkovitch DG. A quorum-sensing signaling system essential for genetic competence in Streptococcus mutans is involved in biofilm formation. $J$ Bacteriol 2002:184:2699-708.

33. Li Y-H, Lau PCY, Tang N, Svensater G, Ellen RP, Cvitkovitch DG. Novel two-component regulatory system involved in biofilm formation and acid resistance in Streptococcus mutans. J Bacteriol 2002:184:6333-42.

34. Burgess NA, Kirke DF, Williams P, Winzer K, Hardie KRet al. LuxSdependent quorum sensing in Porphyromonas gingivalis modulates protease and haemagglutinin activities but is not essential for virulence. Microbiol 2002:148:763-72.

35. Fong KP, Chung WO, Lamont RJ, Demuth DR. Intraand interspecies regulation of gene expression by Actinobacillus actinomycetemcomitans LuxS. Infect Immun 2001:69:7625-34.

36. Roberts AP, Cheah G, Ready D, Pratten J, Wilson M et al. Transfer of TN916-like elements in microcosm dental plaques. Antimicrob Agents Chemother 2001:45:2943-6.

37. Chen T, Hosogi Y, Nishikawa K, Abbey K, Fleischmann $\mathrm{RD}$ et al. Comparative whole-genome analysis of virulent and avirulent strains of Porphyromonas gingivalis. $J$ Bacteriol 2004:186:5473-9.

38. Burne RA. Oral streptococci. Products of their environment. J Dent Res 1998:77:445-52.

39. Forng RY, Champagne C, Simpson W, Genco CA. Environmental cues and gene expression in Porphyromonas gingivalis and Actinobacillus actinomycetemcomitans. Oral Dis 2000:6:351-65.

40. Marsh PD, McKee AS, McDermid AS. Continuous culture studies. In: Shah HN, Mayrand D, Genco RJ, editors. Biology of the species Porphyromonas gingivalis. Boca Raton, FL: CRC Press,1993:105-23.

41. Marsh PD. Are dental diseases examples of ecological catastrophes? Microbiol 2003:149:279-94.

42. Takahashi N, Nyvad B. Caries ecology revisited: microbial dynamics and the caries process. Caries Res 2008:42:409-18.

43. Ter Steeg PF, van der Hoeven JS, de Jong MH, van Munster PJJ, Jansen MJH. Enrichment of subgingival microflora on human serum leading to accumulation of Bacteroides species, peptostreptococci and fusobacteria. Antonie Van Leeuwenhoek 1987:53:261-72.

44. Marsh PD, McDermid AS, McKee AS, Baskerville A. The effect of growth rate and haemin on the virulence and proteolytic activity of Porphyromonas gingivalis W50. Microbiol 1994:140:861-5.

45. McDermid AS, McKee AS, Marsh PD. Effect of environmental $\mathrm{pH}$ on enzyme activity and growth of Bacteroides gingivalis W50. Infect Immun 1988:56:1096100.

46. Percival RS, Marsh PD, Devine DA, Rangarajan M, Aduse- Opoku J, et al.. Effect of temperature on growth, hemagglutination, and protease activity of Porphyromonas gingivalis. Infect Immun 1999:67:191721. 
47. Li Y, Burne RA. Regulation of the gtfBC and ftf genes of Streptococcus mutans in biofilms in response to $\mathrm{pH}$ and carbohydrate. Microbiol 2001:147:2841-8.

48. Lo AW, Seers CA, Boyce JD, Dashper SG, Slakeski N, et al. Comparative transcriptomic analysis of Porphyromonas gingivalis biofilm and planktonic cells. BMC Microbiol 2009:9:18.

49. Cario E. Innate immune signalling at intestinal mucosal surfaces: a fine line between host protection and destruction. Curr Opin Gastroenterol 2008:24:725-32.

50. Edelman SM, Kasper DL. Symbiotic commensal bacteria direct maturation of the host immune system. Curr Opin Gastroenterol 2008:24: 720-4.

51. Hooper LV. Do symbiotic bacteria subvert host immunity? Nat Rev Microbiol 2009:7:367-74.

52. Neish AS. Microbes in gastrointestinal health and disease. Gastroenterology 2009: 136: 65-80.

53. Round JL, Mazmanian SK. The gut microbiota shapes intestinal immune responses during health and disease. Nat Rev Immunol 2009:9:313-23.

54. Wilks M. Bacteria and early human development. Early Hum Dev 2007:83:165-70.

55. Dixon DR, Reife RA, Cebra JJ, Darveau RP. Commensal bacteria influence innate status within gingival tissues: a pilot study. J Periodontol 2004:75:1486-92.

56. Canny GO, McCormick BA. Bacteria in the intestine, helpful residents or enemies from within? Infect Immun 2008:76:3360-73.

57. Wehkamp J, Schwind B, Herrlinger KR, Baxmann S, Schmidt K, Duchrow M, Wohlschlager C, Feller AC, Stange EF, Fellermann K. Innate immunity and colonic inflammation:enhanced expression of epithelial adefensins. Dig Dis Sci 2002:47:1349-55.

58. Abraham SN, Jonsson A-B, Normark S. Fimbriaemediated host-pathogen cross-talk. Curr Opin Microbiol 1998:1:75-81.

59. Cosseau C, Devine DA, Dullaghan E, Gardy JL, Chikatamarla A, et al. The commensal Streptococcus salivarius K12.

60. Yilmaz O, Young PA, Lamont RJ, Kenny GE. Gingival epithelial cell signalling and cytoskeletal responses to Porphyromonas gingivalis invasion. Microbiol 2003:149:2417-26.

61. Ter Steeg PF, van der Hoeven JS, de Jong MH, van Munster PJJ, Jansen MJH. Modelling the gingival pocket by enrichment of subgingival microflora in human serum in chemostats. Microb Ecol Health Dis 1988:1:73-84.

62. Marsh PD. Microbial ecology of dental plaque and its significance in health and disease. Adv Dent Res 1994: 8: 263-271.

63. Nackaerts O, Jacobs R, Quirynen M, Rober M, Sun Y. et al. Replacement therapy for periodontitis: pilot radiographic evaluation in a dog model. $J$ Clin Periodontol 2008:35:1048-52.

64. Tagg JR, Dierksen KP. Bacterial replacement therapy: Adapting germ warfare to infection prevention. Trends Biotechnol 2003:21:217-23.

65. Bradshaw DJ, Marsh PD, Watson GK, Allison C. Oral anaerobes cannot survive oxygen stress without interacting with aerobic/facultative species as a microbial community. Lett Appl Microbiol 1997:25:3857.

66. Carlsson J. Growth and nutrition as ecological factors. In: Kuramitsu HK, Ellen RP, editors. Oral bacterial ecology: the molecular basis. Wymondham, Norfolk, UK: Horizon Scientific Press, 2000:67-130.

67. Herrera D, van Winkelhoff AJ, Dellemijn-Kippuw N, Winkel EG, Sanz M. b-lactamase producing bacteria in the subgingival microflora of adult patients with periodontitis. A comparison between Spain and The Netherlands. J Clin Periodontol 2000:27:520-5.

68. Van Winkelhoff AJ, Winkel EG, Barendregt D, Dellemijn- Kippuw N, Stijne A, et al. B-lactamase producing bacteria in adult periodontitis. $J$ Clin Periodontol 1997:24:538-43.

69. Walker CB, Tyler KT, Low SB, King CJ. Penicillindegrading enzymes in sites associated with adult periodontitis. Oral Microbiol Immunol 1987:2:129-31.

70. Baumgartner JC, Falkler WA, Beckerman T. Experimentally induced infection by oral anaerobic microorganisms in a mouse model. Oral Microbiol Immunol 1992:7:253-6.

71. Fabricus L, Dahle'n G, Holm SE, Mo“ller JR. Influence of combinations of oral bacteria on periapical tissues of monkeys. Scand J Dent Res 1982:90:200-206.

72. Metzger Z, Lin Y-Y, Dimeo F, Ambrose WW, Trope M, Arnold RR. Synergistic pathogenicity of Porphyromonas gingivalis and Fusobacterium nucleatum in the mouse subcutaneous chamber model. J Endod 2009:35:86-94.

73. Sundqvist GK, Eckerbom MI, Larsson AP, Sjogren UT. Capacity of anaerobic bacteria from necrotic pulps to induce purulent infections. Infect Immun 1979:25:68593.

74. Van Steenbergen TJM, van Winkelhoff AJ, de Graaff J. Pathogenic synergy: mixed infections in the oral cavity. Antonie Van Leeuwenhoek 1984:50:789-98.

75. Shani S, Friedman M, Steinberg D. The anticariogenic effect of amine fluorides on Streptococcus sobrinus and glucosyltransferase in biofilms. Caries Res 2000: 34: 260-267.

76. Millward TA, Wilson M. The effect of chlorhexidine on Streptococcus sanguis biofilms. Microbios 1989:58:155164.

77. Takahashi N, Ishihara K, Kato T, Okuda K. Susceptibility of Actinobacillus actinomycetemcomitans to six antibiotics decreases as biofilm matures. $J$ Antimicrob Chemother 2007: 9:59-65.

78. Larsen T. Susceptibility of Porphyromonas gingivalis in biofilms to amoxicillin, doxycycline and metronidazole. Oral Microbiol Immunol 2002:17:267-71.

79. Noiri Y, Okami Y, Narimatsu M, Takahashi Y, Kawahara $\mathrm{T}$, Ebisu S. Effects of chlorhexidine, minocycline, and metronidazole on Porphyromonas gingivalis strain 381 in biofilms. J Periodontol 2003:74:1647-51.

80. Socransky SS, Haffajee AD. Dental biofilms: difficult therapeutic targets. Periodontol 2000 2002: 28: 12-55.

81. Zaura-Arite E, van Marle J, ten Cate JM. Confocal microscopy study of undisturbed and chlorhexidinetreated dental biofilm. J Dent Res 2001:80:1436-40.

82. Watson PS, Pontefract HA, Devine DA, Shore RC, Nattress BR, Kirkham J, Robinson C. Penetration of fluoride into natural plaque biofilms. $J$ Dent Res 2005:84:451-5. 